\title{
Mapping Relevance, and Placement Model of Work Practice of Students inVocational High School
}

\author{
Agus Hery Supadmi Irianti \\ Department of Industrial Technology \\ Universitas Negeri Malang \\ Malang, Indonesia \\ agus.hery.ft@um.ac.id
}

\author{
Marniati \\ Department of Home Economics \\ Universitas Negeri Surabaya \\ Surabaya Indonesia
}

\begin{abstract}
This research aims to: (1) selection of industrial workplaces, Implementation of industrial practice, (2) apprenticeship relevance, (3) model placement students. This type of descriptive research approach to quantitative analytical techniques the percentages. The results is boutique fashion program Map at 10 schools, 108 places apprenticeship industry with 6 types of industry, including: couturier, boutiques, tailor, garment factory, teaching clothes. The relevance of the competencies of $\mathbf{4 3 . 1 6 \%}$ relevant. $70 \%$ placement models school choice, and $30 \%$ of the combined model
\end{abstract}

Keywords—mapping, relevance, placement

\section{INTRODUCTION}

Vocational high School are the institutions education that results in human resources to direct entering the workforce being in labor professional, to produce skilled and professional graduates certainly cannot be separated from the role of school and industry as a place of industrial practice, but still found participation industry or school readiness that is less to be maximized in the implementation of the practice of industrial work .It can be proven by the emergence of criticism that graduates vocational high schools are considered less able to follow a change, because of a lack of provision skills obtain the basis for learning basic learning tools [1]. In addition there are faces obstacles congruity qualitative and quantitative so there competency gap owned graduates of vocational education with competence what the world needs industry [2]. Qualitative congruity happened because of technological development in the very rapidly while congruity quantitative happened because the job is to the number of education output seek jobs not comparable [3]. One of the aims of the practice of industrial work is giving a real work experiences that participants control productive.

Skills as standard, An active role the business world and industry in the vocational education is needed. There are significant influence and positive between experience working practices industry, insight into the world of work and competence to work honesty skills [4]. It is also proved in accordance the results of the study that various views of from an industry about Vocational High School, so far they do not know or do not want to know with the concept of double system education where later on students vocational high school graduates is expected to be a worker who reliable
[5]. Research on mapping, relevance, model placement, school readiness and experience practice industrial work Vocational High School student in poor is a solution problems of vocational education program special his expertise of fashion. The purpose of this research to: (1) make a map of the expertise fashion, (2) know relevance the industrial work, (4) know the model assignment students practice industrial work.

Initial description of SMK Conditions of Fashion Programs shows that there are 10 Vocational high school programming clothing and all vocational skill in the field of expertise is butiq clothing; 3 out of 10 Vocational schools have not been accredited; the status of 6 public schools and 4 private. The industry used as a place of industrial work practice amounted to 108 industries consisting of 6 types of industries, namely: Modiste, Boutique, Tailor, Garment, handy craf, teaching factory. The field of expertise is crucial in mapping the placement of students in industrial work and competency mapping that must be provided so that students are really ready to work according to their area of expertise. Exposure shows the whole field of expertise is butiq clothing, but the picture of the place of industrial practice. Vocational high school Program Expertise Dressing as one of the vocational high school have characteristics different from other types of education, which consists of learning activities of theory and practical learning activities with a sizeable portion, the SMK Program Clothing Skill is required to be able to prepare skilled workers quality and meet the competency standards required by the world of work.

\section{METHOD}

The research is descriptive research with the quantitative approach used analysis techniques the percentage. Scope research program is a map expertise, the practice of industrial work associated with: school readiness in the practice of industrial work, relevance, the model, experience students. The research all vocational high school program of fashion expertise in Malang. Research is a whole population students of vocational high school finished implement the practice of industrial work in class XI in 2013/2014. and all the practice of industrial work coordinator vocational school program of fashion expertise in Malang. 


\section{RESULTS AND DISCUSSION}

\subsection{Mapping of Vocational High Schools and Mapping of} Industrial Work Practices.

Mapping Vocational schools Vocational clothing skills program is seen from the number of schools and distribution of schools in each region. In addition mapped also industry as a place of industrial practice. The existing skills program in the vocational school is closely linked to the industry map used as a place of practice. The existence of the two maps provides a basis for analyzing the relevance, both the relevance of the selection of the practice site, the relevance of the competencies acquired in the practice to the counseling relevance during the practice. Research data on mapping of vocational areas of Vocational School and industry map of practice can be described as follows.

TABLE I. VOCATIONAL HIGH SCHOOL CLOTHING SKILL PROGRAM IN MALANG INDONESIA

\begin{tabular}{|l|c|c|}
\hline \multicolumn{1}{|c|}{ District } & $\begin{array}{c}\text { Total Vocational High } \\
\text { School }\end{array}$ & \% Fashion Expertise \\
\hline Malang City & 4 & 100 \\
\hline Malang istrict & 5 & 100 \\
\hline Batu City & 1 & 100 \\
\hline
\end{tabular}

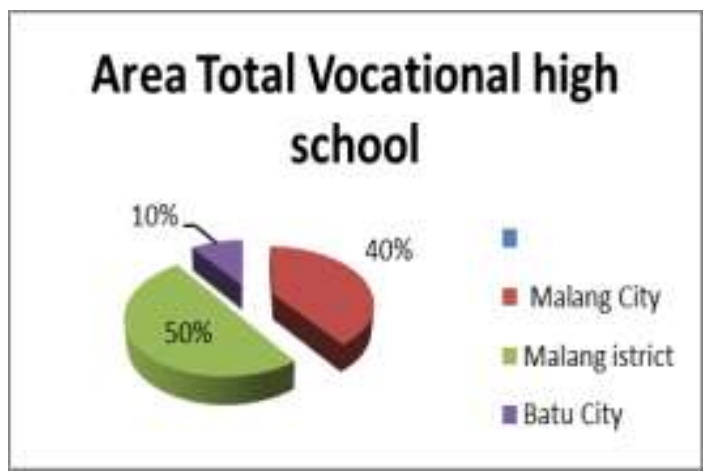

Fig.1 Diagram Vocational High School Clothing Skill Program

TABLE II. TYPE OF INDUSTRY PLACE OF PRACTICE

\begin{tabular}{|l|c|c|c|c|c|c|}
\hline \multirow{2}{*}{ Area } & \multicolumn{7}{|c|}{ Total Industry } \\
\cline { 2 - 7 } & Modiste & Butik & Tailor & Garment & $\begin{array}{c}\text { Handy } \\
\text { Craft }\end{array}$ & $\begin{array}{c}\text { Teaching } \\
\boldsymbol{F}\end{array}$ \\
\hline $\begin{array}{l}\text { Malang } \\
\text { Cyti }\end{array}$ & 17 & 26 & 15 & 14 & 0 & 0 \\
\hline $\begin{array}{l}\text { Malang } \\
\text { District }\end{array}$ & 17 & 2 & 4 & 4 & 0 & 0 \\
\hline $\begin{array}{l}\text { Batu } \\
\text { City }\end{array}$ & 3 & 2 & 0 & 0 & 1 & 1 \\
\hline $\begin{array}{l}\text { Out of } \\
\text { Malang }\end{array}$ & 1 & 1 & 0 & 0 & 0 & 0 \\
\hline $\begin{array}{l}\text { Total } \\
\text { industry }\end{array}$ & 38 & 31 & 19 & 18 & 1 & 1 \\
\hline$\%$ & 35.19 & 28.7 & 17.59 & 16.66 & 0,93 & 0.93 \\
\hline
\end{tabular}

Between expertise programs and industry workplaces are strongly linked. The type of industry that is selected as a place of industry practice will provide an experience that supports the competence of students who are studied in school. If the selection of the practice site is irrelevant, then it certainly does not provide a meaningful experience for students. This is in accordance with Finch \& Cruncilton's opinion that special compe-tencies for vocational education include tasks, skills, attitudes and values [6].

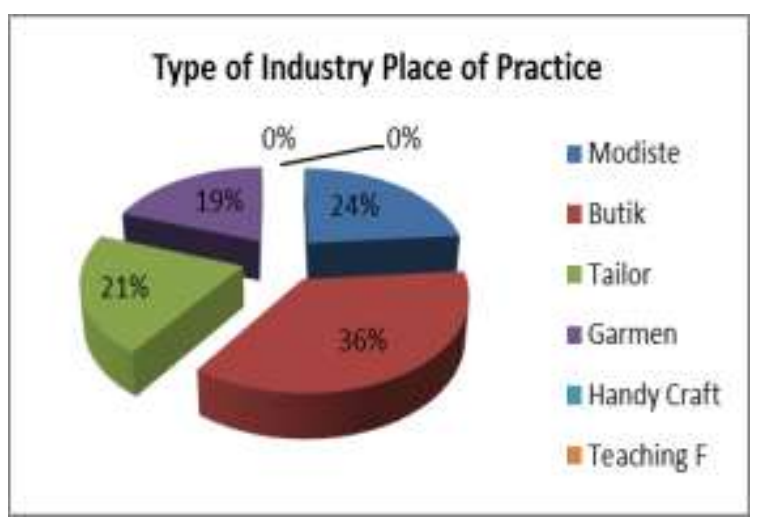

Fig. 2. Diagram type of industry place of practice

If the place of practice is irrelevant will result in the skills that are not provided as needed. If the place of industry used is not appropriate then it will be able to shift the paradigm about technological and vocational learning orientation as disclosed Jones, Valdez, Nowakowski, \& Rasmussen [7].

\subsection{Relevance of selection model of industrial Work Practices}

Model Selection Place Industrial work practice include 4 indicators covering the conformity of the function of the place of industrial practice, the management of industrial work practices, the characteristics of the place of industrial practice. Competence obtained in the place of industrial work practice. From the results of data collection can be arranged table frequency distribution and pie diagram as follows.

The placement model of industrial engineering students there are 3 models, namely prakerin placement model based on student choice, prakerin placement model based on school choice and joint placement model. The data of prakerin student placement model obtained shows that from 10 vocational schools that have boutique clothing skills program there are 7 schools that are in the placement of prakerin students using the school choice placement model and 3 schools using the combined model. Placement model data can be seen in Table 3 .

TABLE III. PLACEMENT MODEL WORKING INDYSTRY STUDENTS

\begin{tabular}{|l|c|c|c|}
\hline \multirow{2}{*}{} & \multicolumn{3}{|c|}{ Placement Model } \\
\cline { 2 - 4 } & $\begin{array}{c}\text { Choice of } \\
\text { students }\end{array}$ & Choice of School & Combined \\
\hline Total & 0 & 7 & 3 \\
\hline$\%$ & 0 & 70 & 30 \\
\hline
\end{tabular}




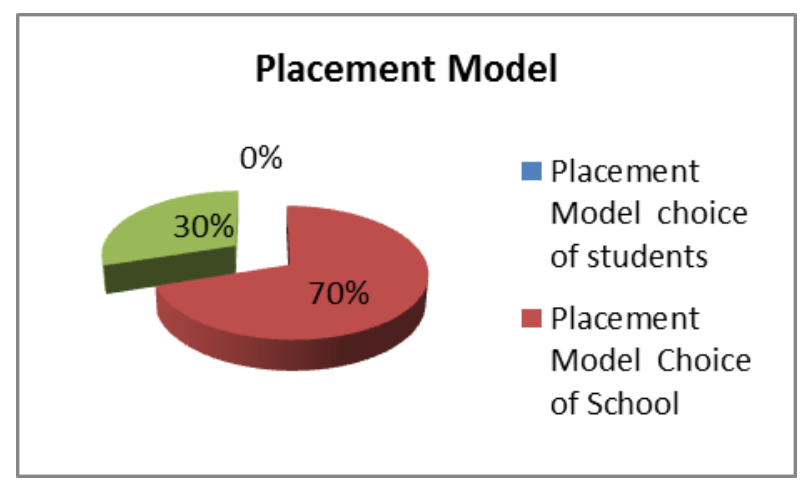

Fig. 3. Diagram Placement Model Working Industry Students

TABLE IV. FREQUENCY DISTRIBUTION RELEVANCE SELECTIONS PLACE OF INDUSTRIAL PRACTICE

\begin{tabular}{|c|c|c|c|c|}
\hline Interval & Category & F & \%f & \% cumulative \\
\hline $61-76$ & Very high & 93 & 35.9 & 35.9 \\
\hline $47-60$ & high & 132 & 51 & 86.9 \\
\hline $33-46$ & low & 32 & 12.4 & 99.3 \\
\hline $19-32$ & Very low & 2 & 0.7 & 100 \\
\cline { 1 - 1 } \cline { 5 - 6 } & 259 & 100 & \\
\hline \multicolumn{3}{|c|}{ Total }
\end{tabular}

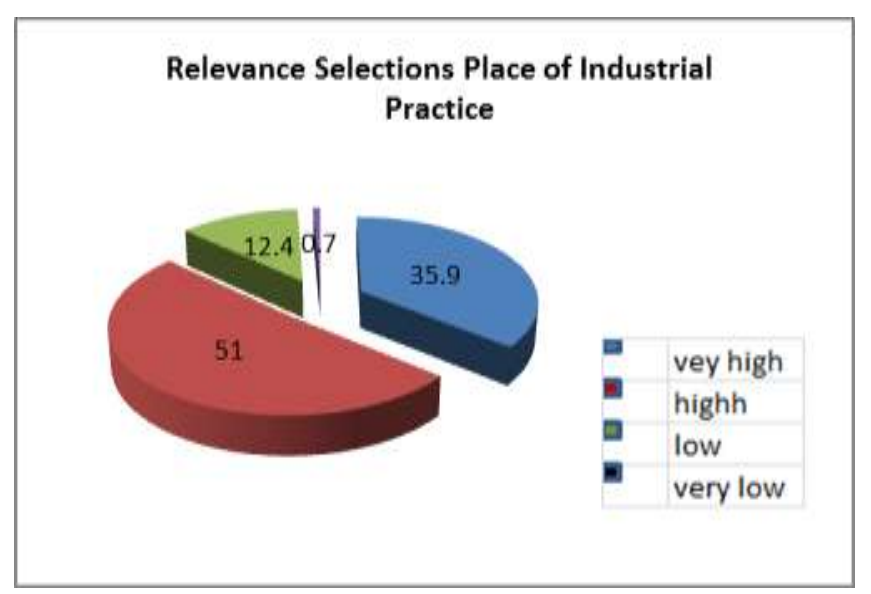

Fig. 4. Diagram Relevance Selections Place of Industrial Practice

The respondents in this study is categorized by the relevance of the selection of prakerin places of $35.9 \%$ very high category, $51 \%$ high category, $12.4 \%$ rendering category and for very low category of $0.7 \%$. The results of empirical research proved the relevance of selection prakerin pertained pertinent pertinent, and generally explain the students of SMK skills program Fashion in Malang has chosen the relevant prakerin place. Relevant prakerin places are expected to provide real-world work experience as expected. According to Oemar Hamalik PI or in some schools referred to as On The Job Training (OJT) is a training capital held in the field, suitable to provide the skills needed in certain jobs in accordance with the benefits of the ability of work (2007;
21). Selection of relevant practice places provides the meanings that students have constructed well. This will provide vocational education opportunities in providing technical skills to enter work [8].

The practice of industrial work is part of system education double must be implemented for students of vocational high school. Through the practice of industrial work that is students will gain experience of real work, gain experience in the competence of, but it depends on industry as the industrial work practice. Not all industry occupied students practice industrial work relevant. Relevant here having a meaning a very wide. Relevant here can in terms of conformity industry as the industrial work and relevance related with competence given or received by students practice industrial work.

The practice model students industrial work in high school program fashion vocational expertise boutique in unfortunate kingdom is a model assignment by election the schools and joint model of schools and students in search of industry as the industrial work mutual cooperation. If the model is determined to the school schools should choose the industrial work with the competence appropriate expertise students program.

Program practice industrial work get competence determined by school, because there are many industrial work practice not qualified by mostly vocational high school in Malang. Lack of guidance for students practice industrial work, and not of feedback in students practice industrial work. Condition in the industrial work having the effect on competence practice industrial work to be accomplished students. The conditions are right can be seen from facilities and infrastructure garages and intensity work students in the industrial work. By means of and infrastructure workshop relevant intensity work students who high in the industrial work able to increase these competence practice industrial work [9].

\section{CONCLUSION}

Based on research data, so which a conclusion can be taken from the study are: a. 10 schools vocational high school in Malang having program fashion boutique expertise. Industry as the industrial work students of vocational high school program expertise fashion boutique in Malang after mapped consisting of 108 industry across Malang city, Malang District, Batu City and there are two industry in Surabaya. The results of the mapping it was known type of industry as the industrial work is: couturier, boutique, tailor, garment, handycraft, and teaching factory. Relevance election the industrial work students of vocational high school program of fashion expertise in malang students implement the practice of industrial work in Malang. Model placement students practice industrial work there are two kinds of the model placement by the school and model placement joint, namely model placement students practice industrial work school working with her pupils. Model 
placement by school is reaching 7 school (70\%) the rest combained model.

\section{REFERENCES}

[1] Sidi, I., 2002 Menuju Masyarakat Pembelajar, Menggagas Paradigma Baru Pendidikan, Jakarta, Paramadina bekerjasama dengan Logos Wacana Ilmu.

[2] Sumarno.2008. Employability dan Pengaruhnya terhadap Penghasilan Lulusan SMK Teknologi dan Industri. Jurnal Kependidikan Lembaga Penelitian UNY Tahun XXXVIII. Nomor 1, Mei 2008, LLPM UNY. Yogyakarta.

[3] Syahril IS.2012. Model Analisis Pencapaian Kompetensi Kejuruan Berdasarkan Fasilitas Praktik Pada Sekolah Menengah Kejuruan Dengan Pendekatan Sistem Dinamis.Reposatory.UPI accessed 10 Januari 2013

[4] Putriatama Ega, dkk. 2016. Kontribusi Pengalaman Praktek kerja industri, Wawasan Dunia Kerja Dan Kompetensi Kejuruan Melalui Emplo yability Skill Serta Dampaknya Terhadap Kesiapan Kerja Lulusan Sekolah Menengah Kejuruan Kompetensi Keahlian Teknik Komputer Dan Jaringan Di Probolinggo Jurnal Pendidikan: Teori, Penelitian, Dan Pengem bangan. 2016;1(8)

[5] Widiyanto dan Sri Utaminingsih. Strategi Peningkatan Kompetensi Lulusan Sekolah Mene ngah Kejuruan (Sekolah Menengah Kejuruan) Jurusan Bisnis dan Manajemen Berbasis Dunia Usaha Dan Dunia Industri (Dudi). Diakses 17 April 2013

[6] Finch,C.R. \& Crunkilton. J.R. 1984. Curriculum Development In Vocational and Technical Education. London: Allyn and Bacon, Inc

[7] Jones, B.F., Valdez, G., Nowakowski, J.,\& Rusmussen, C. 1994. Designing Learning, and Technology for Educational Reform. NCREL

[8] Felder,R.M.1993. Reaching the second Tier: Learning $\begin{array}{ll}\text { and Teaching Style in College Science Education. } & \text { J } \\ \text { Collage Science Teaching, 23(5), } 286\end{array}$ 290.http:www2.ncsu.edu/unity/lochers/ users/f/felder/ public/RMF.html

[9] Kusuma, F.I. 2010. Hubungan Kualifikasi Tempat Praktek kerja industri dan Intensitas Kinerja Siswa di Tempat Praktek kerja industri dengan Capaian Kompetensi Praktek kerja industri Siswa Keahlian Teknik Mekanik Otomotif SMK Negeri 6 Malang. Jurusan Pendidikan Teknik Mesin. Skripsi tidak diterbitkan. Malang: Universitas Negeri Malang 